\title{
THE BURIAL OF THE VON ADLERBERGS OF VIRU-NIGULA IN THE CONTEXT OF THE 19TH CENTURY
}

\author{
Kristiina Johanson, Tõnno Jonuks, Jana Limbo-Simovart
}

\begin{abstract}
The article analyses archaeological excavations which were carried out in the county of Lääne-Viru in the Viru-Nigula churchyard. During the excavation a tomb with two burials was opened - a woman, buried in 1821, and a man, buried in 1841, were studied. From the head of the coffin five sets of glass plates with silhouette portraits were unearthed. These are unique in the 19th-century Estonian context and contemporary examples are not known from neighbouring areas either. In addition to the example from Viru-Nigula tomb, an overview is given of the situation of research into burials of Modern Age as a whole.
\end{abstract}

Keywords: Viru-Nigula, tomb, 19th-century burials, silhouette portrait, glass painting

On the 25th of July, 2004, the grave-stone of Gustav Hasselblatt, a long-time pastor of Viru-Nigula (served in the years 1815-1863) was reopened in the churchyard of Viru-Nigula. It was a cross once erected for the pastor, his wife and their four children that had now been restored together with the base for the cross and a plate with the names of the buried. This majestic event had brought here the offspring of the Hasselblatts who otherwise live a long distance from Estonia. When leaving the cemetery after the opening ceremony the participants noticed a big hole next to the path leading to the churchyard. The collapsed burial chamber that had remained unnoticed on the ground so far belonged to the owner of the manor of Vana-Varudi (Old-Varudi) and later Uue-Varudi (New-Varudi) namely, Friedrich Johann Theodor von Adlerberg and his wife Christina Juliana von Adlerberg (Figure 1). A special mystique is hidden behind the seemingly accidental concurrency. The history of the local church includes a legend of a young pastor Gustav Hasselblatt who, after his first sermon in front of the Viru-Nigula congregation, faced negative criticism from a church vestryman, Friedrich von Adlerberg. This was the beginning of the years' long dislike between the two men. The animosity has probably not calmed 


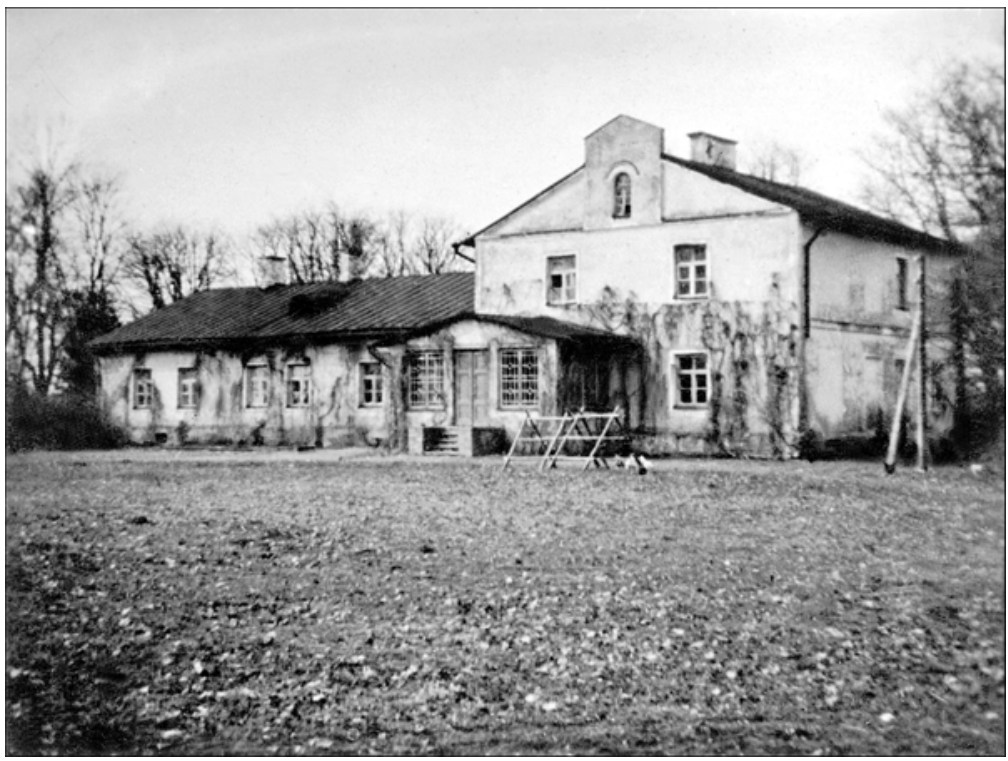

Figure 1. Main building of the Uue-Varudi manor. Photo from the collection of the Estonian National Museum.

down until the present day and culminated in 2004 with the collapse of the burial chamber of F. J. T. von Adlerberg at the exact same time that a new and restored grave stone was placed on the resting place of the Hasselblatts.

Leaving aside the hostility between the two stubborn men, the collapse of the burial chamber does not seem such an astonishing accident after all. There may be many explanations, starting with the weak and careless masonry of the vault. The fact that owing to the underground vault the burial chamber has remained hidden, has been detrimental to the chamber, as this has allowed people to walk over the vault for more than a hundred years. The chamber's location on the 9th quarter of the Viru-Nigula churchyard, not far from the main entrance of the church and the path leading to it, made stepping on the vault possible, whereas access to the rest of the churchyard, in turn, opened on the path and thus led directly over the vault. It is also possible that the crumbling of the vault was partly brought about by the rainy summer of 2004 during which the 
remaining mortar from the corners of the vault that were already weakly connected was washed out.

After the collapse of the burial chamber, the local municipal government of Viru-Nigula was caught in a dilemma: whether to respect the peace of the dead and fill the chamber with sand or open the tomb, clear the burials, document them and thereafter fill the tomb. In Estonia sites of this type have been studied only briefly and the topic has not attracted the interest of historians either. Thus we cannot consider our knowledge of the burial custom of the nineteenth-century nobility to be adequate. The National Heritage Board, the pastor of the Viru-Nigula congregation and the local government agreed with the archaeologists that filling the chamber without scientific research would simply result in the loss of information. Therefore it was decided to open the chamber, and the process was started at the end of the summer.

The detailed overview of the course of the research has been published elsewhere (Johanson \& Jonuks 2005) and will not be repeated here. However, some of the assumptions presented in the article will be reviewed and the interpretations that remained inconclusive at the time are presented as new.

\section{THE STUDY OF MODERN AGE (18TH-19TH-CENTURY) BURIALS AND CEMETERIES IN ESTONIA}

Estonian archaeologists have very rarely engaged themselves in studying Modern Age burials. The subject has been mostly approached in investigations of churchyards and churches, and even then as part of rescue excavations. In these cases we are predominantly dealing with burials belonging to the 18 th and the 19 th century. The reason that lies behind is the decree of Catherine II from 1774, which put an end to burying inside town churches and churchyards. As a result new cemeteries were founded further from the churches and settlements. Thus the 18th-19th-century burials in churchyards are the best preserved ones since the earlier are mostly mixed burials. Even if burying into churches was abandoned after the decree was issued, burying in churchyards, at least as far as rural churches were concerned, was nevertheless continued. In these churches the old family burial places that belonged to influ- 
ential lords of manor were still in use. Thus the latest dates of the interments in Estonian parish churchyards remain in the 19th-20th century, exceptions (ministers, for example, sometimes depending on the cemetery), however, can be found all through the 20th century.

Modern Age cemeteries located away from churches have been archaeologically studied primarily in the course of rescue excavations and this has concerned the town burial places (among the biggest of such is the eighteenth-century cemetery on Tartu Lillemägi, where altogether 546 burials were unearthed (see Kalling 1991)). The majority of scientific research has concentrated on chronologically earlier problems: identifying and studying the prehistoric burial grounds beneath the present churchyards, the relationship between prehistoric religion and Christianity or analysing medieval burials and death culture (Valk 2001; Rudi 2003).

Although research of this period has taken place on several burial sites, in-depth studies are nevertheless missing. Registering and describing cemeteries has been quite thorough (see Bärenson \& Viires 1990). The work focused mainly on describing single objects in the graveyard and documenting the blueprints of the cemeteries that are no longer used. Parallelly with the inventories, a few studies were completed as well, for example the overview of Estonian wheel crosses by Lembit Odres (1983).

Overviews of rescue excavations, however, have been mentioned only passingly in different publications. The reason for this practice is perhaps the tacit agreement that the archaeologically interesting period in Estonia ended with the Great Northern War (17001721). Moreover, Modern Age burials, especially in towns where more cemeteries have been excavated, are poor in findings. Considering the ample data on burial customs and religion in other sources, primarily written documents, it is understandable why burials of this period have attracted only little scientific interest.

While numerous studies have been published on the burial traditions and death culture of medieval towns (see Loit 2006 and references), the material concerning death and burials of later periods has not attracted profound scholarly interest. However, a few extremely important studies on Modern Age art and architecture, in- 
cluding sacral and memorial art have been published (see Kodres et al. 2005). Unfortunately, smaller chapels have not attracted any special attention either. Single burial chambers have remained unanalysed altogether.

These Modern Age burials that have contained mummified bodies have probably proved to be the most popular (Hermann 1976; Moora 1976; further on this see Peets \& Samma 2002). The earliest of these date back to the beginning of the 17th century but the main part of the known mummies have been dated to the 18th and the 19th century. While former researchers considered mummification a natural process that developed as a result of the interaction of dry climate and lime-rich air (mummies have mostly been discovered in burial chambers and chapels made of limestone, some have been discovered in the sandstone area of South-Estonia as well) (Jung 1897, 1910: 141; Hermann 1976: 577), scholars of later periods tend to favour the explanation of intentional and conscious embalming. Tanel Moora regards the natural mummification in Estonia in the even very stabile environment extremely unlikely. Quite the opposite, he makes the assumption that the dead bodies were surrounded with dry hop bines and the coffin was later hermetically sealed (Moora 1976).

Modern Age burials in Estonia have most thoroughly been analysed by anthropologists but their research angle has very clearly been physical anthropology. This is largely owing to the choice of the research object - namely, the bulk of material from medieval and Modern Age village cemeteries where archaeological findings are quite scanty. Anthropologists have mostly concentrated on the craniology of the dead buried in South-Estonian medieval and Modern Age graveyards (Heapost 1995: 57-59) and Tääksi medieval village cemetery (Allmäe 1995: 12-18), stature and sexual dimorphism (Allmäe 2000, 1997) and to some extent also dental and cranial pathologies (on the example of Tääksi, Allmäe 1999).

The topic of death has been important for folklorists as well, especially in the context of the 20th century while changes in the death culture and death omens have been primarily studied, the source being mostly folklore and ethnographical field-work (Ristolainen 2004; Mikkor 2001). 
Still, there have been several exciting investigations on objects chronologically closer to the von Adlerbergs that contribute to the better understanding of the observed burial chamber and its placing into a wider context. The most important of these have been completed not by archaeologists but restorers in the course of the conservation works on the burial memorials and remains of nobility of the second half of the 18th and the beginning of the 19th century (see Peets \& Peets 2002; Peets 2002; Peets \& Samma 2002). Although the studies predominantly concentrate on the conservation problems of the material, they do offer background information necessary for interpreting the wider issues.

Although both the chapel of Barclay de Tolly in Jõgeveste and the chapel of Wassermanns in Hargla represent the tradition of south Estonia, it does not play an important role whereas all the buried belong to the nobility and are thus independent of local traditions. Also the subterranean chamber in Viru-Nigula should not hamper the comparison with the chapel burials, since in case of the chapels the coffins have been placed in the basements under the chapel

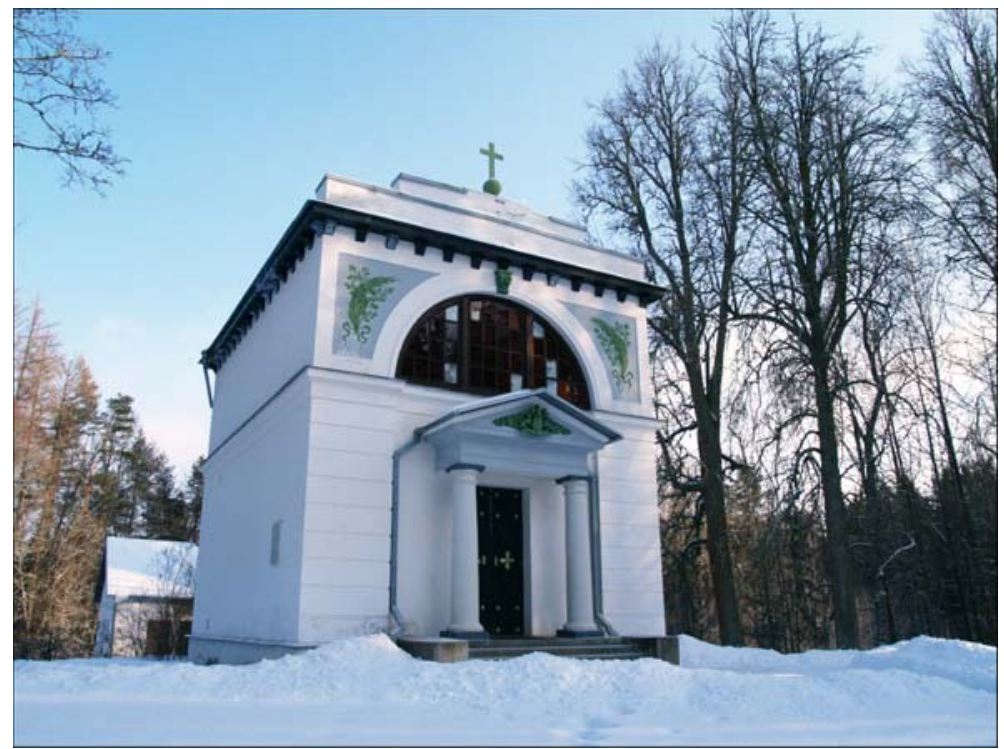

Figure 2. The mausoleum for Barclay de Tolly completed in 1823 in Jõgeveste. 
floor as well (Figure 2). Richly decorated coffins both in rural and town cemeteries are typical of the burials of the nobility during the observed period. In town and rural graveyards of the period primarily only few nails have been preserved of the coffins. In some cases few objects connected with the clothing can be found in the cemeteries, for example belt buckles, whereas coins related to the deceased, so typical of earlier burials, are completely missing. The burials of the nobility include coffin handles with decoration plates, usually brocade bands; other discovered ornamentation includes tufts and fringes. However, except for the coffin handles there are no "obligatory" decoration elements of the coffin. The rest probably depended on the wealth and aesthetic taste of the relatives of a particular deceased person. Thus there might be a crucifix attached to the coffin cover (Peets \& Peets 2002; Peets 2002) but this is not a mandatory element (Figure 3). Unfortunately there are no written sources concerning grave goods placed into the coffin to accompany the dead, the artefactual material is usually lacking as well. The latter circumstance, however, might not reveal the adequate situa-

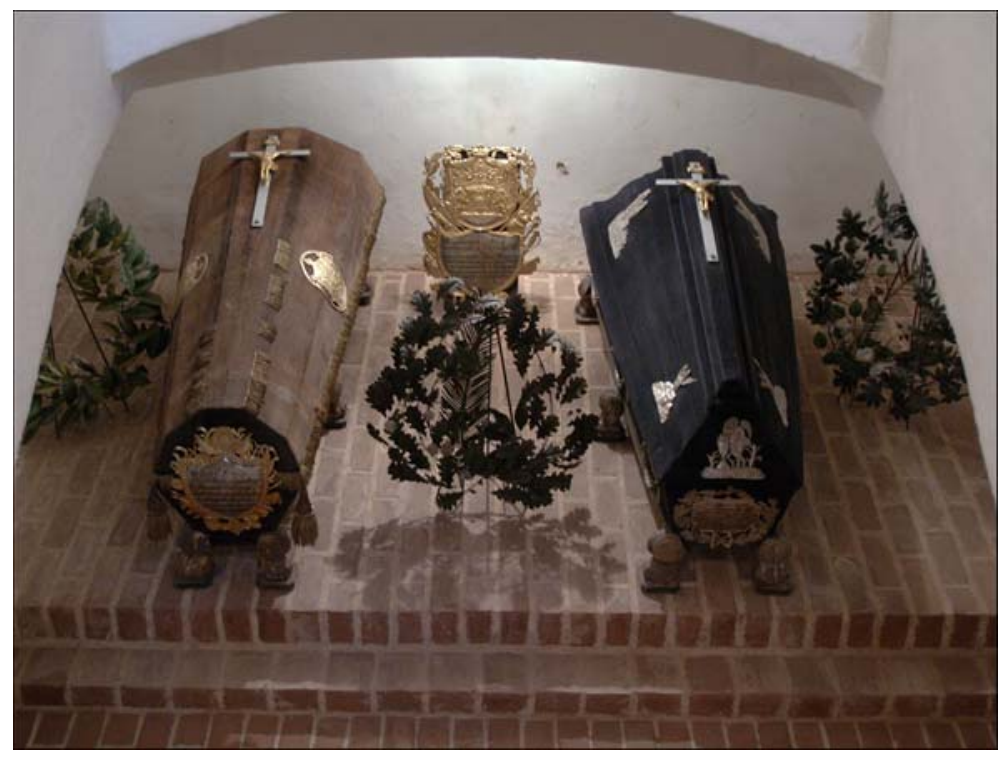

Figure 3. The coffins of Michael Andreas Barclay de Tolly and Helene Auguste Eleonore von Smitten in Jõgeveste in the mausoleum cellar of de Tolly. 
tion since many of the coffins in burial chambers were the prey of looting already in the past (Peets \& Samma 2002: 30) and as mentioned above, the burials of the nobility of the second half of the 18 th century and the 19th century have not been studied systematically. In addition, the burial of the von Adlerbergs in Viru-Nigula, which will be discussed in more detail below, refers to artefacts placed in the coffin.

\section{CASE STUDY OF THE BURIAL CHAMMBR OF THE VON ADLERBERGS IN VIRU-NIGULA CHURCHYARD}

Since the vault of the burial chamber had collapsed, the work started with removing the crumbled stones and the soil from the chamber. In the course of this work six coins (dating to the middle of the 16th century to the beginning of the 18th century), both prehistoric as well as medieval pottery sherds, nails, pieces of roof tiles and numerous human bones in a state of disorder were gathered. Bones from the total of 33 individuals were determined but none were represented as a whole skeleton (Limbo 2004). The majority of the bones were broken. It was obvious that the bones had been placed on the underground vault of the burial chamber immediately after laying of the vault whereas petrified lime mortar was found on several bones. The position of three skulls on the vault in the corners of the chamber walls are suggestive of the intentional placing of the bones. This seems to point to even earlier burials the bones of which have been exhumed during the digging of the burial chamber and were later reburied at the same place.

At this point a human tooth which root had been sawed through and a bronze plate had been placed on the incision should be mentioned. The initial assumption that it might have served as a denture does not seem to hold true as the bronze plate would have caused blood poisoning if it had come into contact with blood in the mouth. Still the tooth might be connected with the denture designed specifically for the dead to give a better impression of him/her. The cosmetic perfecting of the dead has been widely practised at the end of the 20th century (see Mikkor 2001). Earlier data on the custom are nevertheless missing in Estonia. 
The presence of prehistoric and medieval pottery on the vault of the burial chamber can be explained with the mixing of the soil. Prehistoric pottery sherds found in the soil appear to be suggestive of the existence of a former settlement site on the location of the existing churchyard (Tamla 1993). Medieval pottery sherds serve as evidence of a medieval cemetery and rituals carried out on the site (see Valk 2001: 81-83). This also explains the discovery of coins in the cemetery (ibid. 83-84). Characteristically, the number of coins decreases in cemeteries and offering places after the Great Northern War and throughout the 18th century. The majority of the coins in Estonian graveyards are dated to the 16th-17th century, coinciding with the deposition of hoards in medieval cemeteries (see Valk 2001: 83). The phenomenon is also consistent with the spread of coins inside the church, for example, the coins found in the course of the research in the Kadrina church can all be dated to the period of 1582-1710. The coins above the burial chamber of the von Adlerbergs date back to the same period, 1565-1731. In the first half of the 18th century the disappearance of findings from churches and churchyards can be observed almost everywhere in Estonia. The process is mostly connected with the decree of Catherine II mentioned above. At the same time the development had begun slightly earlier and burying in village cemeteries had largely been abandoned already during the beginning of the century and by the 1730s (Valk 2001: 90). The latter, however, were not affected by the decree of Catherine. One reason for this might be the recent end of the Great Northern War and new developments brought along by it. The coins gathered in the Viru-Nigula cemetery also demonstrate their disappearance at the beginning of the 18th century, even though burying there was continued. Very likely this is also the case in other churchyards. Thus it may be speculated that there have been some changes in the religious images during the first years of the 18th century. Chronologically it coincides with the beginning of several new religious movements in Estonia (see Plaat 2001). It is possible that changes in folk belief that were reflected by abandoning the habit of placing coins as grave goods or offering practices in the cemeteries (Valk 2001: 80, 83) are connected with pietism that started to spread predominantly in the first years of the 18th century and developed into the most influential movement in Estonia during the 1720s-1730s (Laur 1995). Mati Laur believes that the new religious movements at the beginning of the 18th cen- 
tury actually introduced the ideas of Reformation to the Estonian population whereas the actual Reformation movement passed the rural areas without leaving any trace (Laur 1995: 168).

\section{THE BURIED}

Two burials of east-west orientation were placed on the floor of the burial chamber measuring $225 \times 204 \mathrm{~cm}$ (Figure 4). The burials directed to the west (and thus facing east) are predominant in the Christian tradition and are based on the coming of Christ on Doomsday described in the Gospel according to St. Matthew 24: 27: For as the lightning cometh out of the east and shineth even into the west, so shall also the coming of the Son of man be. Burials directed from east to west are nevertheless exclusively dominating in the Christian tradition. Burials orientated to the north, south, as well as east have been found in almost every studied cemetery (Tamm 2002: 123) and among others also in monastic burial grounds (St. Michael's monastery in Tallinn, Franciscan friary in Rakvere, etc.). The orientation to the west has not been absolute in the case of burials in chambers either, although the direction has generally been followed there. An exception is the burial chamber under the chapel of Hargla where the placement of coffins depends on the dimensions of the chamber and thus some of the coffins follow the north-south orientation. Although the chamber has been raided on several occasions and burials and coffins damaged (Peets \& Samma 2002: 30), it is still not likely that all the coffins have initially been orientated from east to west since the small chamber would simply not accommodate eight coffins.

The northernmost of the two burials in the burial chamber of the Viru-Nigula churchyard was that of a female, supposedly Christina Juliana von Adlerberg (born de Colongue; born 10.03.1771, died 09.02.1821 $1^{1}$ of tuberculosis in Uue-Varudi) and the southernmost was that of a male, probably Friedrich Johann Theodor von Adlerberg (born 1767, died 16.05.18412), the major serving in the Russian army. The deceased have been identified according to the cross leaning on the western wall of the burial chamber which had the following text on its eastern side: 
... herr Mayor und Ritter

... ich Theodor Adlerberg

... 1767 gest. d. 16. Mai 1841

und dessen Gemahlin Christiane

J. Adlerberg geb. Colonge geb. d.

10. März 1771 gest. d. 2. Febr. $1821^{3}$

The left arm of the cross has been broken off and lost and thus we do not know the beginning of the lines. Another text has been engraved into the western side of the cross but the text is so faint that it could not be deciphered.

Friedrich von Adlerberg was the owner of the manor of Vana-Varudi (Alt-Wartz, Wardes since 1841). He was in close relations with captain Hans de Colongue, who was the owner of the Uue-Varudi (NeuWartz) manor and Friedrich's father-in-law. In his will dated to the year 1812 (signed in 1819) Hans de Colongue names his daughter Christina as one of his inheritors who thus became the owner of the Uue-Varudi manor. Both Friedrich and Christina von Adlerberg

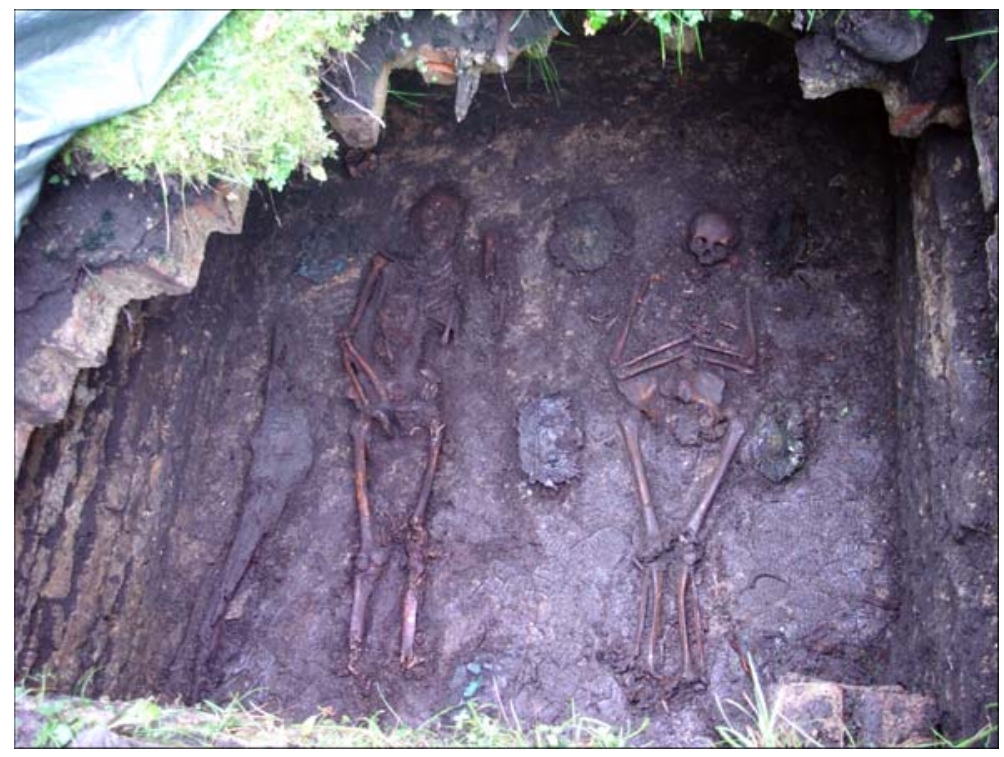

Figure 4. The main burials of the chamber. A view from east. 
were intimately connected with the church, whereas Friedrich belonged to the vestry of the church as the representative of the Varudi manor(s) (first only Vana-Varudi, later also Uue-Varudi) at least until 1820. According to the archive sources the Adlerbergs had five grown-up children. ${ }^{4}$

The height of the buried man was $170-173 \mathrm{~cm}$, which is more than the average considering the average stature of the men at the period $(164 \mathrm{~cm})$. It could probably refer to slightly better living conditions in case of which the actual height potential of the person could be fully revealed. The average stature of Estonian men in the period has been estimated according to the height of the men recruited in the Russian army in 1818-1827 (Aarma 1987), all of whom were of rural background and thus coming from harsher living conditions. Most pathologies of the deceased were age-related, for example osteoporosis or bone rarefaction and osteophytes or the bony excrescences of the vertebrae that both cause rheumatism. In addition, hyperostosis in the eye sockets could be documented which is caused by anemia from iron deficiency and indicates inflammatory processes in the body. It was difficult to make any conclusions about the nutrition on the basis of the wearing of teeth, since the discovered body was old and many teeth had fallen out most likely as a result of paradontosis long before the death. The front lower incisors had fallen out already in his younger age as a result of a possible trauma. At the same time, the absence of caries suggests diverse eating habits, but also a small amount of refined sugars in the food. The strongly developed points of muscle attachment to the bones reveal that the man had been physically active during his lifetime and engaged in actions that required strong muscles - physical work or perhaps riding. Especially unique were the artificial slanting traces of wearing on the right teeth of the lower jaw.

The height of the buried woman was $158 \mathrm{~cm}$, which was above the average $(154 \mathrm{~cm})$. True, the earliest systematic measuring of the stature of females took place as early as in 1900-1902 in Tartumaa and thus the obtained result reflects the situation of a century later. The average height of females of the slightly earlier period has been measured $152 \mathrm{~cm}$ in the Kohtla-Järve cemetery on bodies from the 17th-18th century (Allmäe 1997; Heapost 2003). This makes Christina von Adlerberg still a taller than an average woman of the 
time. Osteoporosis could be detected on all the bones and was relatively more developed than on the bones of the man who was 24 years her senior. Also today the frequency of osteoporosis in women increases after the menopause, a common consequence of the disease is bone fractures. In the given case there were no traces of fractures on the preserved skeletal material, which might refer to the good living conditions that made the developing of osteoporosis to such an extent without any bone fractures possible. Among other pathologies, a rheumatic disease caused by the serious osteophytes of the vertebrae and chronic maxillary sinusitis should be mentioned. The growing together of the alveoli refers that most of the teeth had fallen out a long time before the death and the woman had lived without teeth during the last years of her life. Similarly to the man, the strong points of muscle attachment to long bones are indicative of her physical activeness.

\section{COFFINS}

The coffin of the female body has not been preserved. As to the decoration of the coffin, nothing more than simple handles could be found. Neither clothing nor jewellery of the deceased was preserved. Both the coffin of Anna Elisabeth von Münnich, built in Lübeck in 1747 and buried in the Lübeck chapel in St John's Church in Tartu (Peets $\&$ Peets 2002) (Figure 5) as well as the coffin of Helene Auguste Eleonore de Tolly (von Smitten) in the chapel of de Tolly in Jõgeveste (Peets 2002) were lavishly decorated. In addition to draping the coffin with textile they were also adorned with rich metal ornaments and a crucifix was placed to the cover of both coffins. Nevertheless, adorned coffins for the females are not a very common phenomenon.

Judging by the absence of coffin decorations the burial of Christina von Adlerberg could be compared to contemporary cemetery inhumations without findings (see Kalling 1991), although the metal coffin handles form an exception. The handles suggest that the coffin had initially been decorated, covered with cloth as befits the period, and probably differed from the coffins of contemporary commoners in better finishing and richer decoration. At the same time it is not comparable to the burials of the nobility of the period. 
In case of the male burial the boards of the oak coffin had been in most parts preserved. There were three coffin handles on either sides of the coffin which were relatively fancy, decorated with flags and initially probably laid in coloured enamel (Figure 6). Double brocade band enwrapped in bronze wire ran along the sides of the coffin, probably between the edge of the coffin and the lid of the coffin. In addition, decoration knobs enwrapped in bronze wire were placed into every corner of the coffin. The clothing of the buried had not been preserved except for a few bone buttons that had been used to fasten coat lapels and pockets. In terms of footwear, only the bootleg of a left leather boot had been preserved.

An exceptional find was discovered in the head of the coffin of the male burial where four sets of glass plates were unearthed around the head of the deceased in a semi-circle. Counting from the north these were oval, round, round, and oval, whereas plaster frame was preserved around the oval plates. Unfortunately the frames were so poorly preserved that they fell apart immediately after lifting. In addition, a single square plate without any painting was found on top of one of the round ones. A round and oval set consisted of two plates. After the removal of the plates, another set of glasses was found deeper, directly next to the male body's skull. It had an engraved silhouette portrait on it whereas the painting could not be discerned on the upper plates after their finding. Considering the position of the plates it was initially supposed that in the case of the four upper sets we might be dealing with the decoration of the cover of the coffin and the plate with the painting was probably a grave good (Johanson \& Jonuks 2005: 169). This seemed to be confirmed by the plaster frame around the two sets which was supposedly meant to fix the plates onto the coffin cover. Nevertheless, analysing the material later, the belief that all the glasses were inside the coffin and the first four lay in a semi-circle around the head of the deceased and the fifth one next to his head has strengthened.

Before continuing with the analysis of the glass plates, another finding which is relatively difficult to interpret should be mentioned. The head part of the coffin of the male burial had been relatively well-preserved and during the cleaning it was possible to discern the boards of the coffin. A whole skull and a sacrum were found in the southwestern corner of the burial chamber that had remained under the collapsed coffin boards. Both bones belonged to a man 


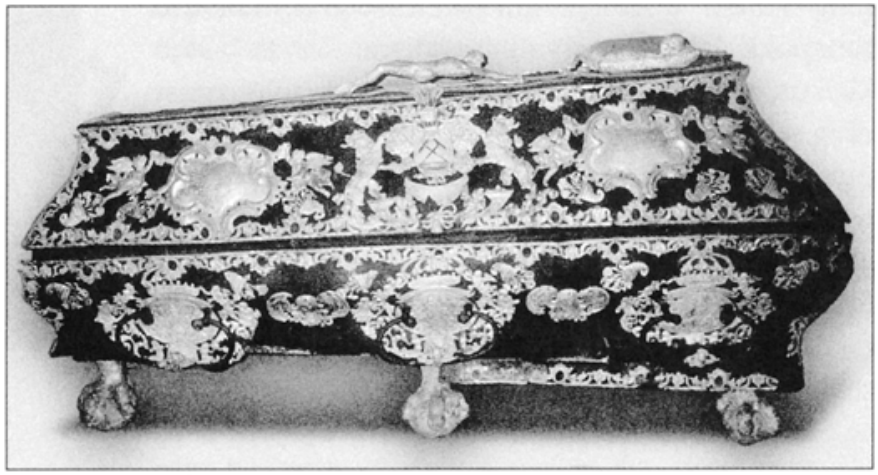

Figure 5. The coffin of Anna Elisabeth von Münnich, dated to 1747, in the Tartu City Museum.

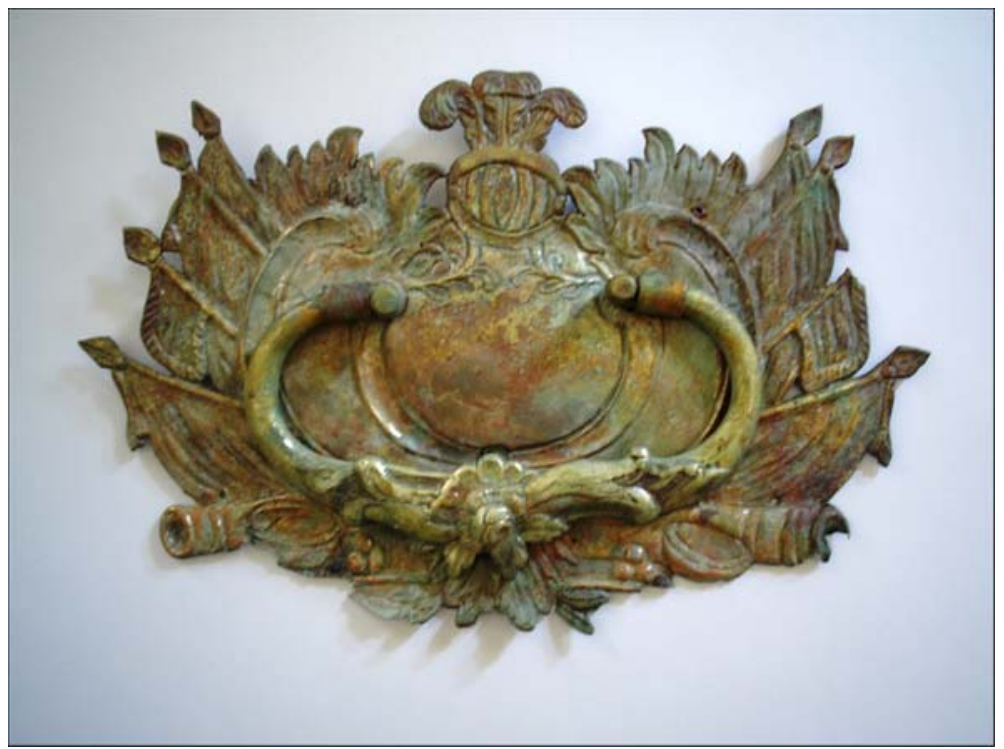

Figure 6. The handle of the coffin of F. J. T. von Adlerberg. 


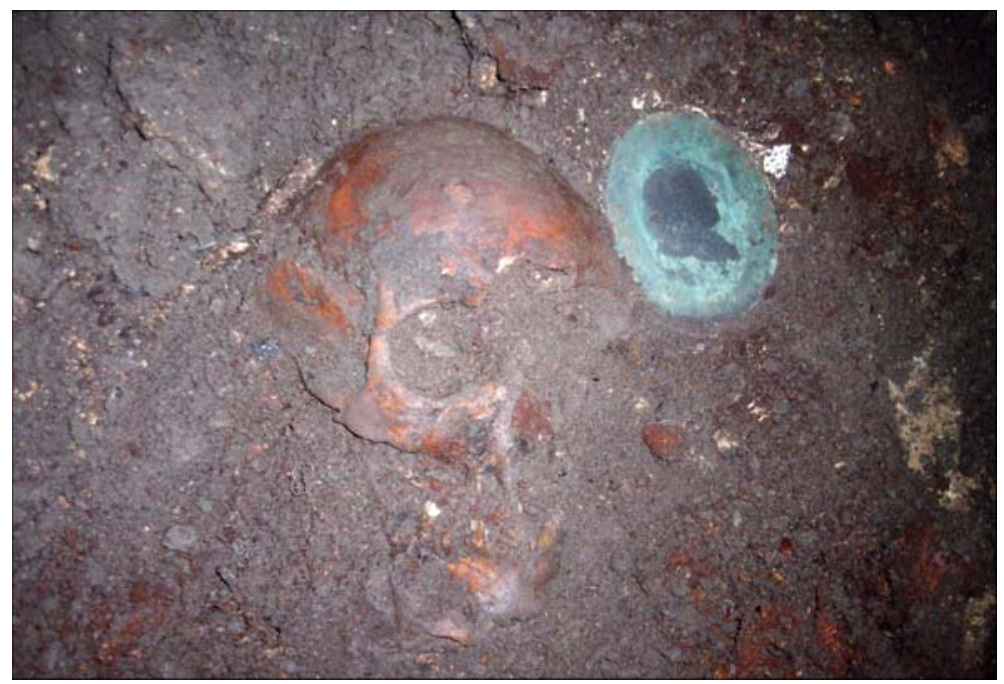

Figure 7. The oval glass plate with the silhouette from beside the head of F. J. T. von Adlerberg.

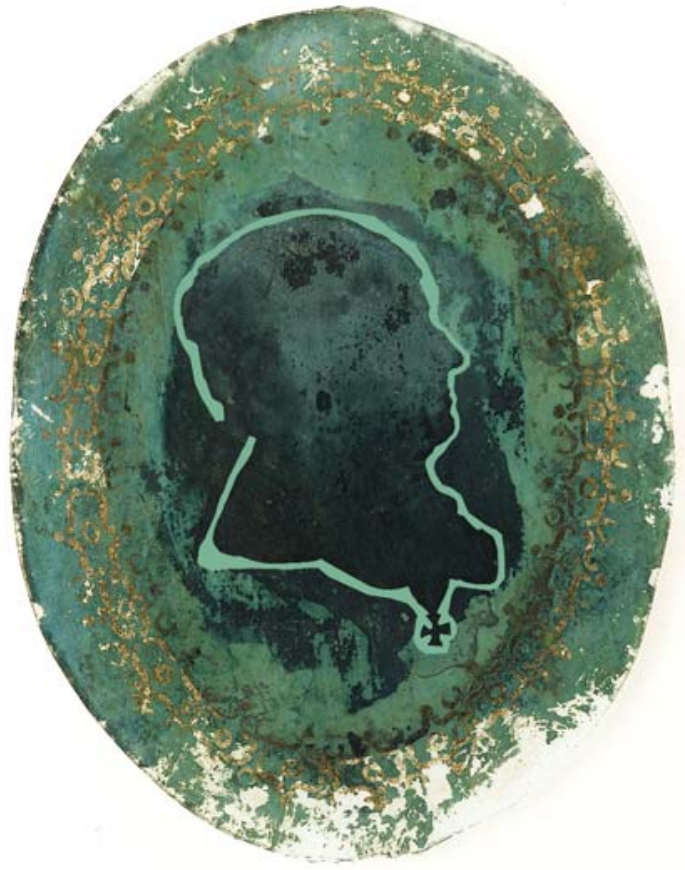

Figure 8. The oval glass plate with the silhouette from beside the head of F. J. T. von Adlerberg. Reconstruction by Conservation Centre Kanut. 
aged $45 \pm 5$ years, possibly to the same individual. Whereas the bones were left under the coffin boards, their reaching into the chamber accidentally after the collapse of the vault is ruled out and thus the skull and the sacrum, both comparatively big and solid bones, had to be in the chamber before the burial of the man took place. We will return to the subject afterwards when analysing the construction of the chamber.

\section{GLASS OVALS}

All the uncovered sets consisted of two 1.5-2 $\mathrm{mm}$ thin plates of cylinder glass, the oval plates measured $11-13 \mathrm{~cm}$ and the round ones $10 \mathrm{~cm}$. While the plates of both round sets had been cut quite precisely, the oval sets, the northern and the southernmost, had been cut out very unevenly and with long cuts. Since the oval plates were surrounded by plaster frame, it can be speculated that their edges could be uneven while being placed in the frame. Each set consisted of an uncoloured plate which was probably meant to preserve the coloured background and the painted glass plate of greenish colour with an engraved human silhouette profile in the middle. Every painted plate had a unique engraved decorative belt around its edge, the engraving of which had been laid in gold colour (gold powder and yellowish adhesive).

All the silhouette portraits in the middle of the glass plates were quite poorly preserved. During the excavation a painting could be discerned on a single plate (Figure 7-8). The painting depicted a portrait of a man and the characteristic feature of the picture was a cross hanging around his neck. It was probably an insignia rather than a religious symbol. Since the plate had been placed next to the body's skull and its position intended to emphasise its meaning, one can expect that the painting did depict the deceased. Nevertheless, it only remains a guess as there is no extant comparative material about F. J. T. von Adlerberg. The plate was girded with a Greek ornament that was composed of various details.

The four other sets of glass plates had been placed around the head of the deceased in a semi-circle. The northernmost set had been surrounded by a plaster frame that was unfortunately so poorly preserved that its exact form was impossible to reconstruct. Both 


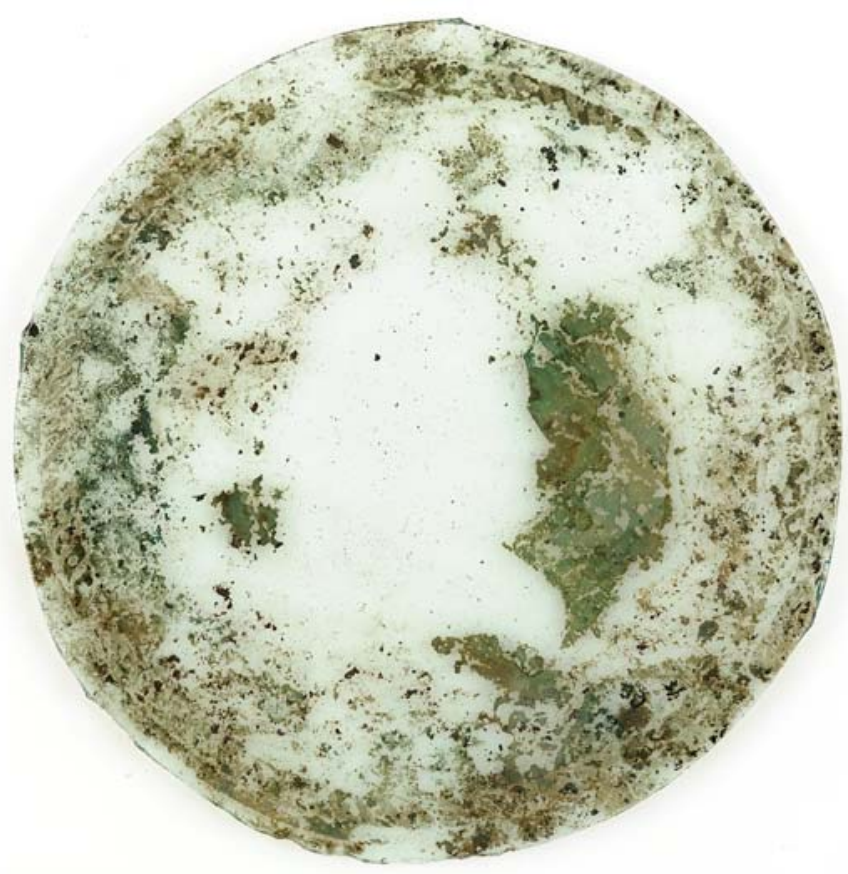

Figure 9. The painted glass from the tomb of F. J.T. von Adlerberg. Photo by Conservation Centre Kanut.

plates had unevenly cut edges and the glass with a painting had a relatively well preserved surrounding meandric ornament. Unfortunately the silhouette had been so badly preserved that it could hardly be discerned.

A set consisting of two round plates was situated directly south of the previous one. Entwining ornament surrounding the central figure on the painted plate (Figure 9 ) of the set was almost intact. The portrait in the middle, however, could be only partly observed. Judging by the low chin and high bust, this might be a portrait of a woman.

Another round set lay more south of the previous one. Ornament of entwined vines fringed the painted plate (Figure 10). The profile in the centre of the plate had been preserved relatively well, undoubt- 


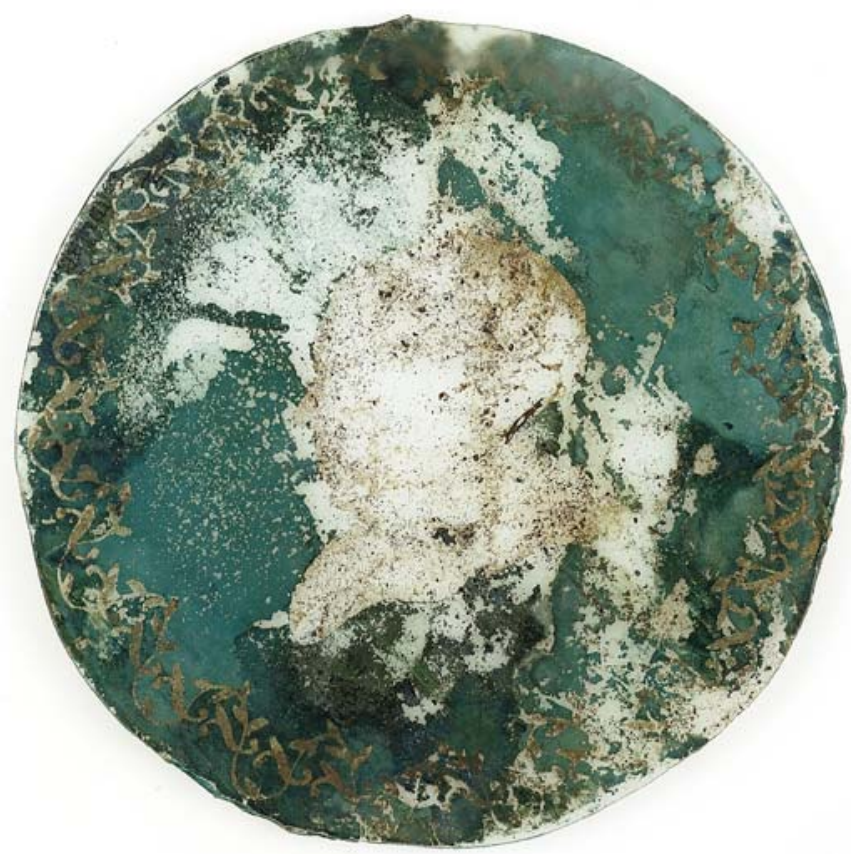

Figure 10. The painted glass from the tomb of F. J. T. von Adlerberg. Photo by Conservation Centre Kanut.

edly depicting a man. In comparison with the possible depiction of F. J. T. von Adlerberg, some similarities could be detected, although as a whole the painting is still different and it is unlikely that they represent the same person.

South of the two round plates there was another set of oval glasses which had a few preserved pieces of plaster frames around it. The plate with the painting (Figure 11) was surrounded by an ornament of vines with big leaves which had been preserved as unbroken framing. The profile of a man was well preserved in the middle of the painting. Unfortunately, the face part of the profile in particular had been destroyed and this does not allow making any assumptions about the similarities or differences with the previous profiles. In addition, a few fragments of silk velvet and some small pieces 


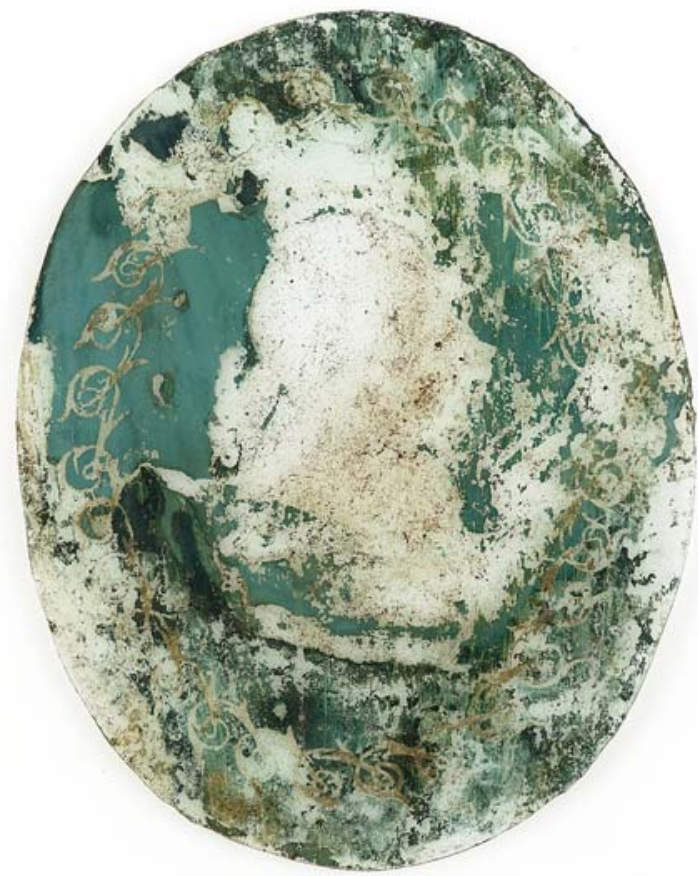

Figure 11. The painted glass of the southernmost set from the tomb of F. J. T. von Adlerberg. Photo by Conservation Centre Kanut.

of paper were preserved on the back of the plate. The paper originated from some printed material but the letter $\mathrm{K}$ and the number 40 that could only be discerned on the paper do not enable to determine the source more specifically.

The glass ovals that were found among the remains of the coffin of Friedrich Johann Theodor von Adlerberg are the expressions of silhouette portrait, a relatively widespread art movement in Estonia, but the find is unique in the context of its finding. In Europe the silhouette depictions were made in the nunneries already during the 17th and 18th century but only in the second half of the 18th century did they become especially popular. On the territory of Estonia the making of silhouette portraits was practised all through the 19th century, losing filigree and elaboration during the first half 
of the century but disappearing as late as in the 20th century. ${ }^{5}$ While in the second half of the 18th century the silhouette portrait was predominantly practised by higher society, then in the first half of the 19th century, owing to the introduction of devices like silhouetting frame and pantograph, the tradition spread among the middle class (Keevallik 1975: 7-8). Thus there is nothing surprising about the fact that Friedrich von Adlerberg, a man of high rank had silhouette(s) of himself (?) done. At the same time we have no comparative material preserved of F. J.T. von Adlerberg that would guarantee with any certainty that the silhouette was made of him. Moreover, although most of the portraits were relatively poorly preserved, it has been ascertained that the portraits do not depict the same person. At the end of the 18th century when the enthusiasm for the antique period ${ }^{6}$ and love for everything intimate and personal grew, silhouette portraits were started to be made in larger quantities. The silhouette portraits were considered the only kind of portrait that could give a representation of the true nature of a person (Keevallik 1975: 7-8). Miniature portraits that were made on the example of silhouette portraits, were made as gifts to intimate friends, they were kept as the tokens of love, friendship and loyalty. Intimacy is enhanced by using the portraits for personal decoration: medallions, bracelets, earrings and finger rings as well as brooches, framing of the portraits and their attaching on the lids of small cases was widespread (Keevallik 1975: 5). The form of portraits changed with the distribution of silhouette art, while the ways in which they were used remained the same. Thus it is possible that the portraits in the coffin of the von Adlerbergs did not depict the major himself but some of his good companions or friends whose signs of friendship and loyalty were important enough to be placed in the grave.

The piece of silk velvet found behind one of the glass plates together with the piece of paper with indecipherable text could be connected with the production technology of silhouette portraits. In the $1780 \mathrm{~s}-1790 \mathrm{~s}$, the earlier technique of cutting, drawing or painting was replaced by golden glass silhouette where the background and depiction of the drawing scratched into gilded glass with a needle was made in black paint, or black textile or cloth set behind the glass (Keevallik 1975: 8). The silhouettes next to the head of F. J. T. von Adlerberg were made with opaque glass paint (green, 
yellow and brown tones) which covered the glass plates, the profiles had been scraped into the painted plates. The depiction was brought out by paper or cloth placed behind the glass and the pieces of these had been preserved behind one of the plates. As to the paper we might even be dealing with an old newspaper the other side of which had been painted black and which was reused for the silhouette art. The piece of silk velvet could have been placed between two glasses (in order to recall, both the oval and round glass plates were found as pairs of an unpainted glass and a painted one) for other reasons as well: for example to fix them together or to facilitate the framing.

\section{THE CONSTRUCTION OF THE BURIAL CHAMBER}

In-depth research on the burial chambers of churches and churchyards are completely absent in Estonia. Established terminology is lacking as well. It is easier to distinguish between the two terms, chapel and burial chamber, with the chambers under churches and the chapels built next to the church or inside the main building as a separate unit, however, in the case of burial constructions in the churchyard both terms have been used simultaneously (see e.g. Hermann 1976). Surely the topic would deserve a separate treatment, but in the current article the chapel is defined as a building which is entirely or for the most part meant to be above the ground and the burial chamber is a construction that is entirely underground but smaller parts of which (a vault, for example) may remain on the ground.

Burying into churches and churchyards was probably started already immediately after the construction of the churches. The oldest grave stones are the 13th-century trapezoid grave plates, which have initially stayed in the churchyards of West Estonia and the islands of Saaremaa and Muhu (Markus 2003). Burying into churches was started soon after. For example, a grave plate with a date 1305 is known from the Jõelähtme church, the wooden construction of which was originally erected probably already in the 13th century but the original stone structure of which has been preserved and was constructed in the first three decades of the 14th century (Raam 1990: 149). The earliest burial chambers were founded already in 
the Middle Ages but the widespread tradition of building sarcophagi and chambers was started in the 16th century and reached its peak in the 17th-18th century (Kodres 2005). The establishing of more outstanding burial chambers and chapels gained momentum after the Reformation when reformists began to deny the religious meaning of the form and shape of the grave. Thus the graves became a manifestation of social position (Lindahl 1969; Kodres 2005). The background for erecting prominent burial monuments may be considered the ruling Renaissance style. The building and selling of the burial chambers became an important source of income for the churches (Kodres 2005: 303). After the decree of Catherine II from the year 1774, the tradition of building outstanding burial monuments came to an end (although in exceptional cases burying into churches was continued as late as in the 19th century (Mäeväli 2004: 40)). Nevertheless, the research of Early Modern and Modern burial chambers in Estonia is missing.

One reason why burial chambers, especially the earlier ones inside the church, are difficult to date and study is that during the Livonian War, mainly in 1558 but also later, the warring army plundered churches and opened all the chambers for the purpose of finding treasures. Balthasar Russow describes the conquering of Tartu in 1558:

And though most of them [the town dwellers of Tartu] had bricked their gold and silver into the walls and buried it under grave stones in the churches, none of this helped. Because the Russians dug up all the walls and grubbed around all the graves and grave stones and got all the hidden treasures at this time and in due course later as well. (Russow 1967: 116)

A similar description is known about the church of Viru-Nigula. Michael Scholbach, the minister of Viru-Nigula has written in the church chronicle about the year 1657 after the looting of the Russian troops:

Nevertheless God helped us and I got back here to the church of Nigula for Whitsuntide. But how everything here was spoiled in such an awful manner! This I cannot tell. Our church had been wiped out, no doors, chairs, windows, not a single iron nail could be found there anymore. The graves of the dead had been forced 
open, the clothes and the jewellery of the dead had been stolen, the church bells taken away, the church manor completely burned down, all the villages and manors in the surroundings bereaved, so that we could see the destroying of Jerusalem in front of our eyes. The farmers who lived by the church insisted that the enemies had done that, but we could say from many things that they themselves were the criminals who rioted in the church and the church manor as robbers after the enemies had already left. (After Jung 1910: 119)

Of course, the churches and burial chambers were pillaged also later, during the Great Northern War. This is why original medieval chapels and burial chambers have hardly ever been preserved, especially in rural churches. Thus it is not exactly known when the tradition of building burial chambers outside the churches was started. Uno Hermann has assumed a relatively long history of the two burial chambers with onground vault in Lüganuse churchyard, nevertheless leaving it unspecified (Hermann 1976: 576).

Examples of Estonian burial chambers may be observed in Swedish chapels, the more widespread founding of which started after completing the burial chapel of Gustav II Adolf in 1634 in the church of Riddarholm (Lindahl 1969: 126-133). Similarly, Swedish chapels consisted of two parts, the lower basement floor of which was designed for the preservation of coffins and the above chapel floor for commemoration service. This is the way many Estonian chapels in the countryside (Hargla, Jõgeveste) as well as at the churches in towns look like. The construction of separate chapels that were located away from churches became widespread in the 18th century, when separate chapels of the lords of manor became common in Estonia. In addition to the chapels that were meant for burying, the construction of private chapels designed specifically for commemoration services was undertaken in Estonia, for example in the manor of Aa (Hein 1997) in North Estonia. However, the time when exactly was the construction of separate burial chambers in churchyards initiated remains uncertain.

While the technical details of the construction of the burial chamber of the von Adlerbergs have been discussed elsewhere (Johanson $\&$ Jonuks 2005), only the main conclusions and corrections to the previous analysis are offered here. While no signs of an entrance to 
the chamber were detected, it was supposed that the chamber had been built earlier (in the 18th century?) and had been used for burying already then. After that the vault had collapsed for some reason and the chamber was emptied from the earlier burials (the skull and the sacrum in the southwestern corner might have been left behind). The deceased woman was then placed into the chamber and twenty years later the man. Finally a low-arched cylinder vault was laid below the walls of the chamber. It was considered possible that while the western wall of the chamber has been separated from the other walls by a joint, the initial entrance may have situated there and was bricked in later. This type of burial chambers with an onground vault and which upper part of the whole western wall has been open are known elsewhere. A fine example is the Lüganuse churchyard where Jaan Jung has discovered mummified bodies in a burial chamber (Figure 12) (Jung 1910: 141-142). Similar burial chambers which have a narrowing upper part of the open wall are

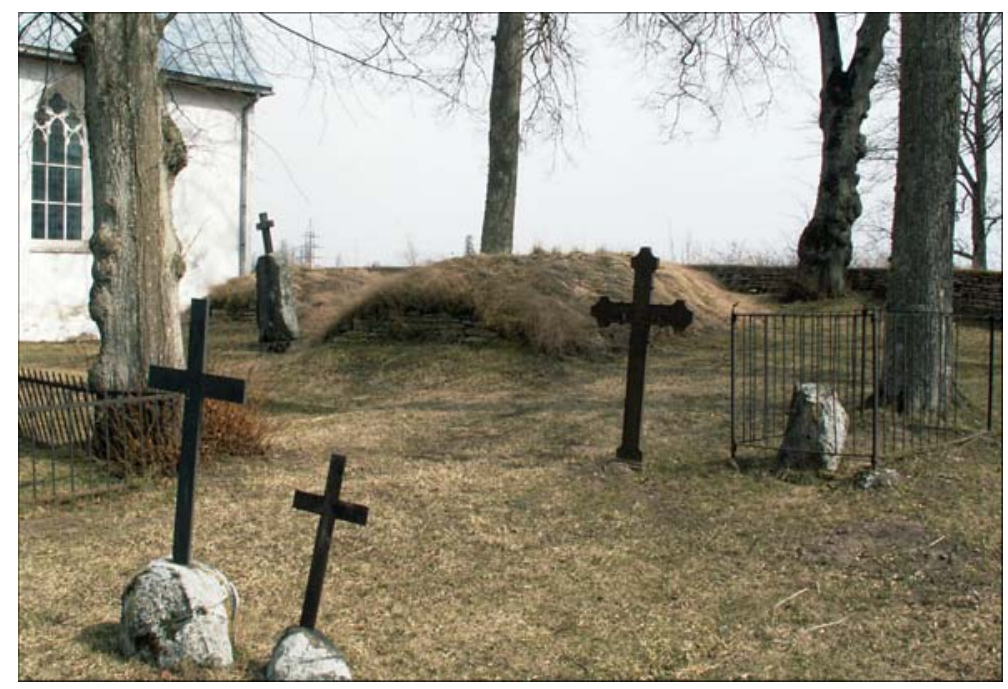

Figure 12. Two burial chambers with onground vault laid of limestone in the Lüganuse churchyard where Jaan Jung discovered mummies at the end of the 19th century: "There was a woman with white face and deep white coif inside one coffin, so intact that had she been familiar, she would have been recognized at once" (Jung 1910: 142). 


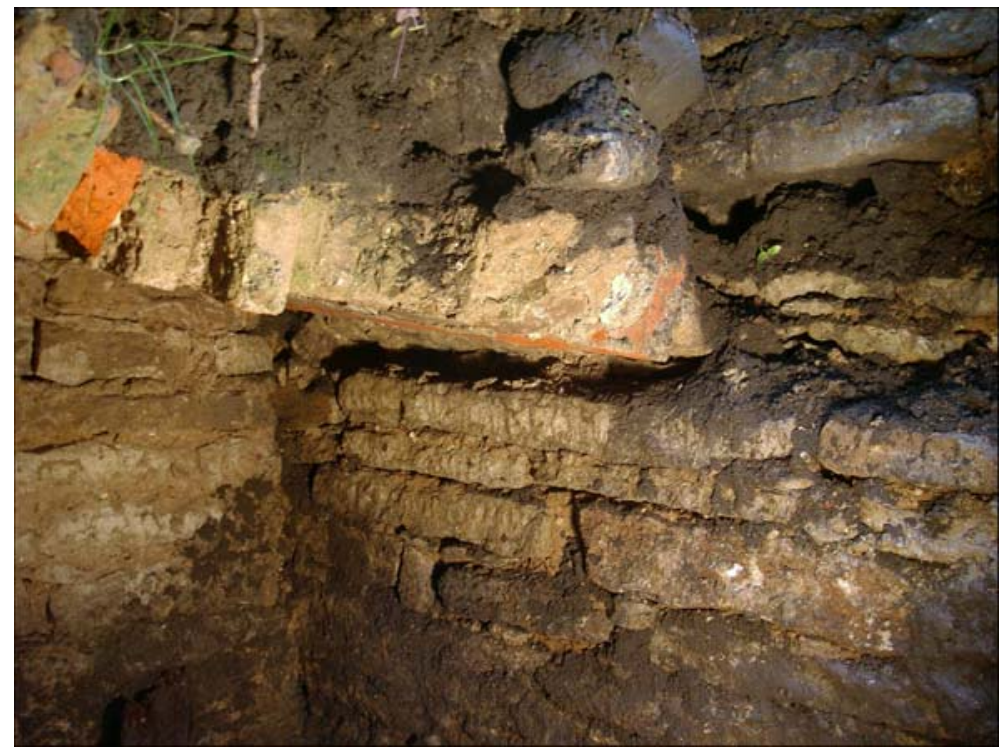

Figure 13. The cylinder vault of the burial chamber of the von Adlerbergs. The vault has been supported by the incised grooves in the long walls of the chamber and covered with soil.

known from the churchyard of Väike-Maarja and one from the ViruNigula churchyard as well.

At the present moment, it seems more likely that the burial chamber was nevertheless built for the von Adlerbergs and has initially been with an onground vault. After the onground vault has been demolished, the grooves have been incised into the walls of the vault which have supported the underground vault (Figure 13) and this has been covered with soil. Human bones were laid on the vault together with the soil, whereas the skulls and other bigger bones had been consciously placed into the corners of the vault so that they would be in as deep as possible. While calcified mortar was found on the majority of the bones, the covering of the vault must have happened immediately after laying the vault. Thereafter the upper open part of the western wall of the chamber has been bricked in the course of which a few bones might have crumbled into the chamber that were planned to be placed on the vault (the skull and 
the sacrum in the southwestern corner of the chamber). After losing the onground vault, a memorial cross has been erected on top of the chamber. It is possible that the faded text on its western side indicates the date of refreshing the vault and erecting the cross.

Other similar "hidden" burial chambers can be found in the churchyard of Viru-Nigula as well as in other rural churchyards.

\section{SUMMARY}

The research of the burial chamber of the von Adlerbergs in ViruNigula demonstrated that we hardly know anything of the burial customs of the 19th century. In addition to the continuously missing information of the construction and dating of the burial chambers the burial customs remain questionable as well. Anyway, the common understanding of Christian inhumations might not hold true for these burials, although there can be no doubt that the von Adlerbergs definitely represented the Christian way. While according to the common Christian way of burial no grave goods should be expected and the dead have just been placed into the grave to wait for the resurrection of the Doomsday, the Estonian burials from the end of the 18 th century and the 19 th century constitute a very rich study material. The majority of rural and town people have been buried according to the Christian practices. The burials of several noblemen are clearly distinct from the latter: they have been mummified, probably the pictures of their friends have been placed into the graves, and spectacular chapels have been constructed on the graves. It is possible that all the novelties are connected with the enthusiasm for the antiquities during the spread of the Enlightenment Movement at the end of the 18th century. This would explain why the novelties spread primarily among the nobility where the new and popular influences were readily adopted. This demonstrates that several and even principally different modes of behaviour can be seen integrated into one religious system. However, there is a great deal of work to be done in the research and understanding of the 18th-19th-century burials.

After the analysis of bones, the remains of Friedrich Johann Theodor von Adlerberg and his wife Christina Juliana von Adlerberg were 
reburied into the chamber in separate coffins. In addition, the human remains that were initially found on the vault were buried in the chamber as well. Although the burial chamber of the von Adlerbergs has hitherto remained unmarked on the ground with a new memorial statue, we still hope that the old men who started a quarrel after a failed sermon almost 200 years ago, have at last found their peace...

\section{Comments}

1 The date of death of Christina Juliana is not exactly known: according to material included in the Estonian Historical Archives it is February 9th but according to the text on the cross February 2nd.

2 The text on the cross gives the year 1841 for the death of Friedrich Johann, at the same time the church records of the Viru-Nigula parish held in the Estonian Historical Archives do not mention his death in this year, at the beginning of 1842 or the last months of the year 1840. To rule out possible spelling mistakes the year 1847 was checked over as well, but without any results. Thus it is possible that F. J. T. von Adlerberg lived somewhere else during the last years of his life.

${ }^{3}$ Deciphering: the inventory list of the Viru-Nigula churchyard from the year 1985, compiled by Ella Rajari, Eduard Rajari.

${ }^{4}$ Materials EAA, 860-1-446.

${ }^{5}$ Although a popular and widespread phenomenon, silhouette art has not been much studied in Estonia. Two other major artists have been established in Estonian art history - J. E. Panck (1805-1851), who completed the silhouettes of the significant figures in Tartu at the beginning and in the middle of the 19th century (Solomykova 1975: 44; Neumann 1908: 117) and A. G. Rauert (who was active as a goldsmith in Tallinn as well as Miitav at the end of the 18th and the beginning of the 19th century), the selection of whose silhouette portraits was held in the art collection of Konstantin Tooming (now held in KUMU - the Art Museum of Estonia). Juta Keevallik is the only art historian who has studied silhouette portraits in Estonia (Keevallik 1975).

${ }^{6}$ The black figure pottery painting became the example of silhouette art. 


\section{References}

Aarma, Liivi 1987. Põhja-Eesti meeste pikkus: võrdlev ajaloolisstatistiline uurimus Eestimaa kubermangust aastail 1811-1874 nekrutiks värvatute andmeil [The Height of Males in North-Estonia: a Comparative Historical-Statistical Study of the Province of Estonia from the Years 1811-1874 According to the Data of Draftees]. Tallinn: Eesti Raamat.

Allmäe, Raili 1995. The changes in craniometric characteristics of children and juveniles (on the basis of Tääksi medieval cemetery). Papers on Anthropology, 6. Tartu, pp. 12-18.

Allmäe, Raili 1997. The stature reconstruction of children on the basis of paleoosteological materials. Papers on Anthropology, 7. Tartu, pp. 4455.

Allmäe, Raili 1999. Dental and cranial pathologies in Tääksi 14th18th cc. skeletal population. Papers on Anthropology, 8. Tartu, pp. 9-14.

Allmäe, Raili 2000. Stature and sexual dimorphism of Estonians in the 13th-18th centuries. Papers on Anthropology, 9. Tartu, pp. 11-23.

Bärenson, Jaan \& Viires, Jaak 1990. Eesti kalmistud [Estonian Cemeteries]. Tiit Masso (ed.). Eesti ehitusmälestised. Aastaraamat [Estonian Monumental Buildings. Yearbook]. ENSV Riiklik Ehituskomitee RUPI „Eesti ehitusmälestised”. Tallinn: Valgus, pp. 122-131.

Heapost, Leiu 1995. On craniology of south-east Estonian population in XI-XVIII cc. Papers on Anthropology, 6. Tartu, pp. 57-69.

Heapost, Leiu 2003. Variation of stature in Estonia from the 12th to the 20th centuries. Papers on Anthropology, 12. Tartu, pp. 51-56

Hein, Ants 1997. Aa mõis [The Manor of Aa]. Eesti arhitektuur [Estonian Architecture], 3: Harjumaa, Järvamaa, Raplamaa, LääneVirumaa, Ida-Virumaa. Raam, Villem (ed.). Tallinn: Valgus, pp. 196-97.

Hermann, Uno 1976. Muumiad Eestis [Mummies in Estonia]. Eesti Loodus, 19. Tallinn, pp. 574-578.

Johanson, Kristiina \& Jonuks, Tõnno 2005. Rescue excavations in the churchyard of Viru-Nigula. Tamla, Ülle (ed.) Archaeological fieldwork in Estonia 2004. Tallinn: Muinsuskaitseamet, pp. 165-179.

Jung, Jaan 1897. Die Mumien von Luggenhusen. Sitzungsberichte der Gelehrten Estnischen Gesellschaft. Jurjew, pp. 44-48.

Jung, Jaan 1910. Muinasajateadus eestlaste maalt [Study into the Ancient Times from the Land of Estonians], III. Kohalised muinasaja kirjeldused Tallinnamaalt. Tallinn: August Busch'i raamatukaupluse kirjastus.

Kalling, Ken 1991. Aruanne arheoloogilistest kaevamistest Tartus, Lillemäel [Report of Archaeological Excavations in Tartu, Lille Hill]. Manuscript in the Archive of EMS AGU. Tartu. 
Keevallik, Juta 1975. Konstantin Toominga kunstikogu kataloog [Catalogue of the Artistic Works of Konstantin Tooming]. Tallinn.

Kodres, Krista 2005. Kirikuarhitektuur Eestis 16.-18. sajandil [Church Architecture in Estonia in the 16th-18th Century]. Eesti kunsti ajalugu, 2. 1520-1770. Kodres, Krista (ed.). Tallinn: Eesti Kunstiakadeemia, pp. $295-314$.

Kodres et $a l=$ Kodres, Krista \& Ehasalu, Pia \& Kuuskemaa, Jüri 2005. Memoriaalkunst [Memorial Art]. Eesti kunsti ajalugu, 2. 1520-1770. Kodres, Krista (ed.). Tallinn: Eesti Kunstiakadeemia, pp. 383-415.

Laur, Mati 1995. Pietism 18. sajandi Baltikumis [Pietism in the 18thcentury Baltics]. Oppetatud Eesti Seltsi Aastaraamat. Annales litterarum societatis esthonicae. 1988-1993. Tartu, pp. 161-169.

Limbo, Jana 2004. Aruanne arheoloogilistest päästekaevamistest ViruNigula kirikaias 30. augustist 3. septembrini 2004. aastal. Lisa II. Antropoloogiline analüüs [Report of Archaeological Rescue Excavation in the Churchyard of Viru-Nigula from August 30 to September 3, 2004. Appendix II. Anthropological Analysis]. Manuscript in the Archives of the Institute of History. Tallinn.

Lindahl, Göran 1969. Grav och rum. Svenskt gravskick från medeltiden till 1800-talets slut [Grave and Space. Swedish Burial Customs from the Middle Ages until the End of the 1800s]. Kungl. Vitterhets historie och antikvitets akademiens handlingar, Antikvariska serien, 21. Stockholm: Almqvist \& Wiksell.

Loit, Mari 2006. Keskaegsest surmakultuurist ja hauatähistest reformatsioonieelse Tallinna kirikutes ja kloostrites [On Medieval Death Culture and Grave Marks in Pre-Reformation Churches and Abbeys in Tallinn]. Pullat, Raimo (ed.). Vana Tallinn, XVII (XXI). Tallinn: Estopol, pp. 13-190.

Loodus, Rein \& Keevallik, Juta 1990. Kunstielu Eestis 19. sajandil [Art Life in Estonia in the 19th Century]. Tallinn: Eesti Teaduste Akadeemia Humanitaar- ja Ühiskonnateaduste Osakond.

Markus, Kersti 2003. Vanimad kristlikud hauatähised Eestis [The Oldest Christian Grave Marks in Estonia]. Mägi, Marika (comp., ed.). Eesti aastal 1200. Tallinn: Argo, pp. 107-124.

Mikkor, Marika 2001. Muutuvast matusekombestikust linnas ja maal [On the Changing Burial Customs in Town and Country]. Eesti Rahva Muuseumi Aastaraamat, IX. Tartu, pp. 103-145.

Moora, Tanel 1976. Mumifitseerimine [Mummification]. Eesti Loodus, 19. Tallinn, pp. 578.

Mäeväli, Sulev 2004. Tallinn Cathedral Burials and Tomb monuments. Morgan Studio.

Neumann, Wilhelm 1908. Lexicon Baltischer Künstler. Riga: Verlag von Jonck \& Poliewsky. 
Odres, Lembit 1983. Eesti rõngasristid [Estonian Wheel Crosses], III. Manuscript in the Archive of the National Heritage Board (KRPI). Tallinn.

Peets, Heige 2002. Barclay de Tolly mausoleum Jõgevestes [The Mausoleum of Barclay de Tolly in Jõgeveste]. Renovatum Anno 2002. Tallinn: Ennistuskoda Kanut, pp. 27-29.

Peets, Heige \& Peets, Jüri 2002. Anna Elisabeth von Münnichi sarga konserveerimine aastatel 1988-1998 [The Conservation of the Coffin of Anna Elisabeth von Münnich in 1988-1998]. Renovatum Anno 2002. Tallinn: Ennistuskoda Kanut, pp. 24-26.

Peets, Heige \& Samma, Markus 2002. Wassermannide erahauakabel. 9. sarga konserveerimine [The Private Chapel of the Wassermanns. The Conservation of the 9th Coffin]. Renovatum Anno 2002. Tallinn: Ennistuskoda Kanut, pp. 30-32.

Plaat, Jaanus 2001. Usuliikumised, kirikud ja vabakogudused Lääneja Hiiumaal: usü̈henduste muutumisprotsessid 18. sajandi keskpaigast kuni 20. sajandi lõpuni [Religious Movements, Churches and Free Congregations in Läänemaa and Hiiumaa: the Processes of Change in Religious Societies from the Late 18th to the End of the 20th Century]. Eesti Rahva Muuseumi sari, 2. Tartu.

Raam, Villem 1990. Uut Harju vanadest kirikutest (Jõelähtme ja Kose) [News about the Old Churches of the Harju County (Jõelähtme and Kose)]. Eesti ehitusmälestised. Aastaraamat. Masso, Tiit (ed.). ENSV Riiklik Ehituskomitee RUPI „Eesti ehitusmälestised”. Tallinn: Valgus, pp. 141175 .

Ristolainen, Tiia 2004. Aspekte surmakultuuri muutustest Eestis [Aspects of Changes in Death Culture in Estonia]. Dissertationes folkloristicae Universitatis Tartuensis, 4. Tartu: Tartu Ülikool.

Rudi, Armin 2003. Kristlased või paganad, varased matused ja leiud Eesti kirikaedades [Christians or Pagans, Early Burials and Finds in Estonian Churchyards]. Bachelor's thesis. Manuscript in the Archives of Estonian Institute of Humanities. Tallinn.

Russow, Balthasar 1967. Liivimaa kroonika. Alamsaksa keelest tõlkinud D. ja H. Stock [The Livonian Chronicle. Translated from Low German by D \& H. Stock]. Stockholm: Vaba Eesti.

Solomykova, Irina (ed.) 1975. Eesti kunsti ajalugu [History of Estonian Art], 1:I. Eesti kunst kõige varasemast ajast kuni 19. saj. keskpaigani. Tallinn: Kunst.

Tamla, Toomas 1993. Viru-Nigula kirik ja Maarja kabel [The Church of Viru-Nigula and St. Mary's Chapel]. Stilus, 4. Lang, Valter (ed.). Tallinn: Eesti Arheoloogiaselts, pp. 18-36.

Tamm, Jaan 2002. Eesti keskaegsed kloostrid [Medieval Monasteries of Estonia]. Tallinn: Eesti entsüklopeediakirjastus.

Valk, Heiki 2001. Rural Cemeteries of Southern Estonia 1225-1800 AD. CCC Papers, 3. 2nd edition. Visby-Tartu. 